\title{
Evaluation of marginal bone loss around platform-switched implants by digital subtraction radiography
}

\author{
Chi-Yoon Kim, Sung-Sook Kim, Hee-Sun In, Yu-Lee Kim* \\ Department of Dentistry, Graduate School, Wonkwang University, Iksan, Repuclic of Korea
}

Purpose: This study is to evaluate the clinical significance of the platform switching concept by comparing the marginal bone loss around platform-matched and platform-switched implants. Materials and Methods: Date of implant placement, diameter, length, implant-abutment connection type and absence of splinting prosthesis were investigated on patients who performed treatment with implant placement at Wonkwang University Dental Hospital Implant Center. To measure the marginal bone loss around implants, periapical radiographs of patient were used when implant was placed and when visited the center most recently by using the program, Emago advanced v5.6. Results: As a result of observing on 150 implants of 82 patients for 6 - 63 months, platformmatched implants showed $1.16 \pm 0.54 \mathrm{~mm}$, platform-switched implants showed $0.68 \pm 0.27 \mathrm{~mm}$ of marginal bone loss. Conclusion: It was considered that there is the positive effect to reduce marginal bone loss around platform-switched implants. (J Dent Rehabil Appl Sci 2015;31(1):33-44)

Key words: platform switching; marginal bone loss; digital subtraction image

\section{서론}

완전 혹은 부분 무치악 부위에 임플란트를 식립하여 상실된 치아를 대체하는 보철수복 방법은 장기간의 높은 성공률이 보고된 이후 여러 환자들이 선택할 수 있는 치 료방법이 되고 있다. ${ }^{1}$ 임플란트를 이용한 보철수복이 보 편화됨에 따라 다양한 종류의 임플란트가 연구 개발되었 으며, 치과의사는 여러 회사의 임플란트를 선택하여 사 용할 수 있게 되었다. ${ }^{2}$

임플란트의 변연골 높이가 유지되는 것은 임플란트의 성공과 생존을 위한 기준 중에서 임플란트 주변 조직의 반응을 확인하기 위한 기준이 된다. 임플란트 수복의 장 기적인 성공을 위해서 임플란트 주변의 골조직과 연조직

*Correspondence to: Yu-Lee Kim

Associate Professor, Department of Prosthodontics, School of Dentistry, Wonkwang University, \#460, Iksan-daero, Iksan, 570-749, Republic of Korea Tel: +82-63-859-2938, Fax: +82-63-857-4824, E-mail: pro11@wku.ac.kr Received: December 16, 2014/Last Revision: March 8, 2015/Accepted: March 2, 2015
이 안정적으로 유지되는 것이 중요하기 때문이다. 일반 적으로 무치악 부위에 임플란트를 식립하고 기능적인 부 하를 시작한 첫 1년 동안 임플란트의 변연골이 약 $1.5-2$ $\mathrm{mm}$ 정도 소실되고, 이후 매년 약 $0.2 \mathrm{~mm}$ 이하가 소실된 다고 보고되었다. ${ }^{1-3}$

임플란트 수복 후 초기 골소실이 발생하는 이유는 수 술 시 외상, 과도한 교합력, 임플란트 주위염, 미세간극 의 존재, 생물학적 폭경 그리고 임플란트 경부 디자인 (crestal module) 등이 있다. ${ }^{4}$ 임플란트의 변연골 소실을 줄이기 위해 수술 시 외상을 줄이고 과도한 교합력이 가 해지지 않도록 조정하며, 임플란트 주위염이 발생하지 않도록 구강위생을 유지하고 임플란트 경부 디자인을 주 의 깊게 선택해야 한다. 하지만 임플란트 주변의 생물학 
적 폭경은 약 3-4 mm로써 자연치의 생물학적 폭경인 $2 \mathrm{~mm}$ 내외보다 크기 때문에, 임플란트 식립 이후 생물 학적 폭경을 형성하는 과정에서 초기 골소실이 필연적 으로 발생하게 된다. ${ }^{4}$ 또한 일반적으로 사용되는 2-piece 형태의 임플란트인 경우 임플란트 고정체와 지대주의 연결부위(implant-abutment junction, IAJ)에 미세간극 이 존재하기 때문에 임플란트의 변연골 소실을 줄이기 가 쉽지 않다. ${ }^{5}$

2006년 Lazzara 등 ${ }^{6}$ 은 임플란트 platform switching 개 념을 소개하였는데, 이는 임플란트 고정체 상부에 보다 작은 직경의 지대주를 연결하여 변연골이 재형성되는 곳을 변화시켜 임플란트의 변연골 소실을 감소시킨다는 것이다. 일반적으로 사용하는 임플란트 고정체와 같은 직경의 지대주를 연결하는 platform matching의 경우와 달리, platform switching을 시행하면 임플란트 고정체 와 지대주 연결부위가 임플란트 platform 내측으로 이 동하여 미세간극이 좀 더 임플란트 내측에 존재하게 된 다. 이에 따라 염증세포의 침윤대가 임플란트의 내측으 로 이동하며 임플란트 주변의 생물학적 폭경이 재형성 되는 부위가 수평적으로 늘어나게 된다. 결국 platform matching을 한 통상적인 임플란트 보철수복과 비교해볼 때, platform switching을 시행하게 되면 임플란트의 변 연골을 좀 더 보존할 수 있다는 개념이다.

임플란트 주변의 골 높이와 골 결함 등을 평가하기 위 해서 치근단 방사선 사진이 일반적으로 사용되고 있다. 하지만 임플란트의 미세한 변연골의 변화를 정량적으로 측정하기에는 한계가 있다. 따라서 임플란트에 관한 연 구와 환자의 정기검진 시 사용하는 진단적인 도구로써 디지털 공제술이 제안되었다. ${ }^{7}$ 디지털 공제술은 컴퓨터 프로그램을 이용하여 시간 간격을 두고 촬영한 두 장의 방사선 사진을 중첩시킨 후 이를 공제하여 경조직 변화 를 확인하는데 유용한 술식이다. 이는 비침습적이고 정 확도가 높은 방법으로 임플란트의 미세한 변연골 소실 을 측정하는데 정량적으로 이용될 수 있다. ${ }^{8}$

따라서 본 연구는 원광대학교 치과병원 임플란트 센 터에 내원한 환자를 대상으로 임플란트 고정체와 지대 주의 직경이 일치하는 platform matching 임플란트와 임플란트 고정체보다 작은 지대주를 연결하는 platform switching 임플란트의 변연골 소실량을 디지털 공제술 을 통해 측정하고 비교하여 platform switching 개념의 임상적 의의를 알아보고자 한다.

\section{연구 재료 및 방법}

\section{1. 환자선택}

2005년 6월부터 2013년 5월 사이에 원광대학교 치과 병원 임플란트 센터에서 임플란트를 식립하고 보철치료 를 시행한 환자 중 임플란트 수복 후 적어도 6 개월 이상 주기적인 관찰이 이루어진 환자를 선택하여 진료기록부 를 조사하였다. 임플란트를 식립한 환자의 수는 총 82명 (남자 43명, 여자 39명)이고, 환자의 연령은 22세에서 76 세의 분포를 보였으며, 평균 연령은 55.3세였다. 총 임플 란트의 개수는 150 개로 platform matching 임플란트는 80개, platform switching을 시행한 임플란트는 70개였 다. 관찰 기간은 6 개월에서 63 개월이였으며, 평균 관찰 기간은 24.9 개월이었다.

\section{2. 진료기록부 조사}

진료기록부를 조사하여 환자의 성별과 연령, 내원 시 기, 임플란트의 식립위치, 직경, 길이, 임플란트 제조사 와 지대주 연결방법, 보철물의 연결고정 유무를 조사하 였다.

\section{3. 임플란트 종류와 분포}

식립된 임플란트 제조사는 외부육각 연결구조 방 식의 Osseotite (Biomet 3i, Palm Beach Gardens, FL, USA) 임플란트 55개, 내부육각 연결구조 방식의 Xive (Friadent, Mannheim, Germany) 임플란트 91개, Pitteasy (Oraltronics, Bremen, Germany) 임플란트 4개였 다. 임플란트의 직경은 $3.75-6.0 \mathrm{~mm}$ 이고, 임플란트 길 이는 8.0 - $15.0 \mathrm{~mm}$ 였으며, platform matching을 시행한 임플란트는 80개, platform switching을 시행한 임플란 트는 70개였다(Table 1).

\section{4. 변연골 소실량 측정}

디지털 치근단 방사선 사진 촬영기 KODAK 2200 Intraoral X-ray System (Kodak-Trophy, Paris, France) 으로 $70 \mathrm{kVp}, 7 \mathrm{~mA}$ 의 조건에서 임플란트 식립 시와 최 근 내원 시에 촬영한 구강내 치근단 방사선 사진을 이용 하였다. CCD 형태의 센서 KODAK RVG 6100 Digital 
Table 1. Distribution of implants used in this study

\begin{tabular}{|c|c|c|c|c|c|c|}
\hline $\begin{array}{l}\text { Implant-abutment } \\
\text { connection type }\end{array}$ & Manufacturer & $\begin{array}{l}\text { Implant } \\
\text { diameter }\end{array}$ & Implant length & $\begin{array}{c}\text { Platform matching } \\
\text { (PM)/ switching } \\
\text { (PS) }\end{array}$ & Implant site & Number \\
\hline External hex & $\begin{array}{c}\text { Osseotite } \\
\text { (Biomet 3i, Palm } \\
\text { Beach Gardens, } \\
\text { FL, USA) }\end{array}$ & $\begin{array}{l}\varnothing 3.75 \mathrm{~mm}: 1 \\
\varnothing 4.0 \mathrm{~mm}: 28 \\
\varnothing 5.0 \mathrm{~mm}: 25 \\
\varnothing 6.0 \mathrm{~mm}: 1\end{array}$ & $\begin{array}{l}8.5 \mathrm{~mm}: 6 \\
10.0 \mathrm{~mm}: 35 \\
11.5 \mathrm{~mm}: 11 \\
13.0 \mathrm{~mm}: 3\end{array}$ & $\begin{array}{l}\text { PM: } 40 \\
\text { PS: } 15\end{array}$ & $\begin{array}{l}\text { Mx. P.: } 6 \\
\text { Mx. M.: } 11 \\
\text { Mn. P.: } 7 \\
\text { Mn. M.: } 31\end{array}$ & 55 \\
\hline \multirow{2}{*}{ Internal hex } & $\begin{array}{c}\text { Xive } \\
\text { (Friadent, } \\
\text { Mannheim, } \\
\text { Germany) }\end{array}$ & $\begin{array}{l}\varnothing 3.8 \mathrm{~mm}: 20 \\
\varnothing 4.5 \mathrm{~mm}: 56 \\
\varnothing 5.5 \mathrm{~mm}: 15\end{array}$ & $\begin{array}{c}8.0 \mathrm{~mm}: 4 \\
9.5 \mathrm{~mm}: 23 \\
11.0 \mathrm{~mm}: 33 \\
13.0 \mathrm{~mm}: 24 \\
15.0 \mathrm{~mm}: 7\end{array}$ & $\begin{array}{l}\text { PM: } 40 \\
\text { PS: } 51\end{array}$ & $\begin{array}{l}\text { Mx. P.: } 9 \\
\text { Mx. M.: } 28 \\
\text { Mn. P.: } 10 \\
\text { Mn. M.: } 44\end{array}$ & 91 \\
\hline & $\begin{array}{c}\text { Pitt-easy } \\
\text { (Oraltronics, } \\
\text { Bremen, } \\
\text { Germany) }\end{array}$ & $\varnothing 4.9 \mathrm{~mm}: 4$ & $12.0 \mathrm{~mm}: 4$ & PS: 4 & $\begin{array}{l}\text { Mx. P.: } 0 \\
\text { Mx. M.: } 2 \\
\text { Mn. P.: } 1 \\
\text { Mn. M.: } 1\end{array}$ & 4 \\
\hline
\end{tabular}

Mx. P., maxillary premolar; Mx. M., maxillary molar; Mn. P., mandibular premolar; Mn. M., mandibular molar.

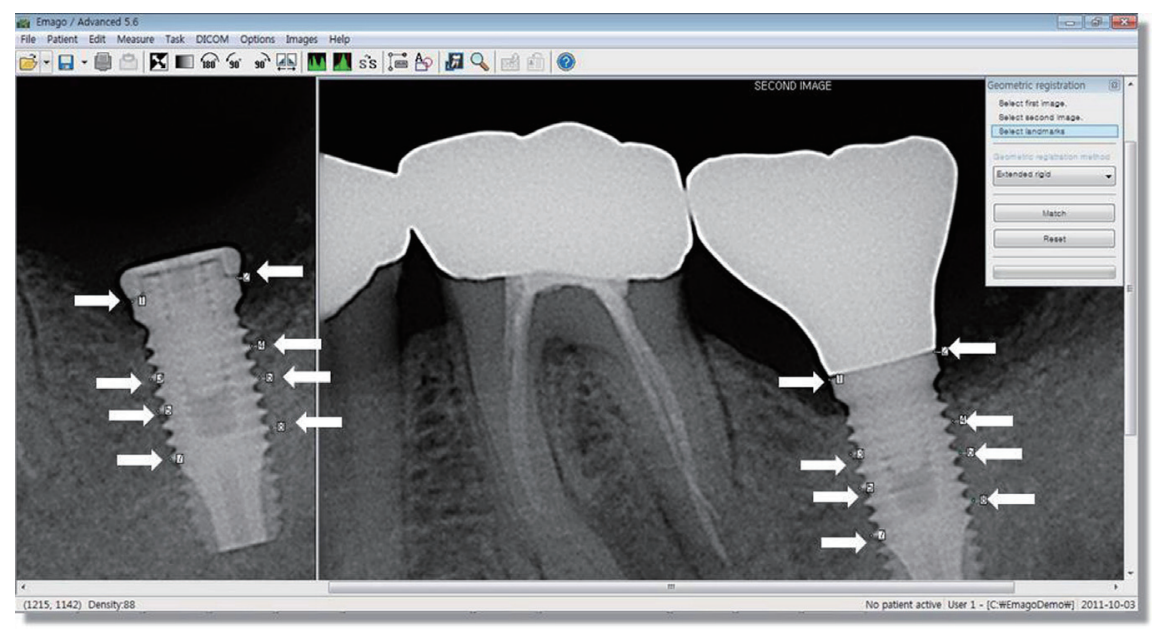

Fig. 1.8 reference points in $100 \%$ expanded pictures.

Radiography System (Carestream Dental, Atlanta, GA, USA)을 통해 촬영한 영상 정보를 $\pi$ viewSTAR (INFINIT'T, Seoul, Korea)를 이용하여 DICOM 영상으 로 전환하고 이를 Tiff 파일로 변환하여 개인용 컴퓨터 에 저장하였다.

Emago advanced v5.6 (Oral diagnostic systems, Amsterdam, Netherlands) 프로그램으로 임플란트 식립 시와 마지막 내원 시 촬영한 사진을 $100 \%$ 확대하여 동 일한 위치에 각각 8 개의 참고점을 설정하고(Fig. 1), 설 정된 참고점을 기준으로 마지막 내원 시의 사진을 기하
학적으로 표준화시키고 대조도와 흑화도를 일치시킨 사 진을 획득하였다. 이후 획득된 사진을 임플란트 식립 시 에 촬영된 사진과 공제하여 최종적으로 디지털 공제 사 진을 얻었다.

최종적으로 획득한 디지털 공제 사진에서 임플란트 platform의 길이(D')를 측정하고, 이에 수직으로 임플란 트 근원심의 변연골 소실량 $\left(\mathrm{L}^{\prime}\right)$ 을 각각 측정하여 아래의 비례식을 이용하여 실제 임플란트의 변연골 소실량을 계산하였다(Fig. 2). 
$\mathrm{L}=\mathrm{D} \times \mathrm{L}^{\prime} / \mathrm{D}^{\prime}$

L: actual amount of marginal bone loss (mm)

L': measured amount of marginal bone loss ( $\mathrm{mm}$ )

D: actual diameter of implant fixture platform (mm)

D': measured diameter of implant fixture platform (mm)

\section{5. 통계분석}

Platform matching 임플란트와 platform switching 임 플란트의 변연골 소실량을 비교하기 위하여 독립표본 $\mathrm{t}$ 검정을 시행하였다. Platform 형태에 따라 임플란트 직 경, 길이, 지대주 연결방법 및 보철물 연결고정 유무가 임플란트의 변연골 소실에 미치는 영향을 알아보기 위 해서 일원배치 분산분석(One-way ANOVA)을 사용하 여 통계처리하였으며, 사후분석은 Tukey HSD test를 사 용하였다. 모든 통계는 SPSS 12.0 (SPSS Inc., Chicago, IL, USA) 프로그램을 이용하였으며, 유의확률이 0.05 이하인 경우 유의하다고 평가하였다.

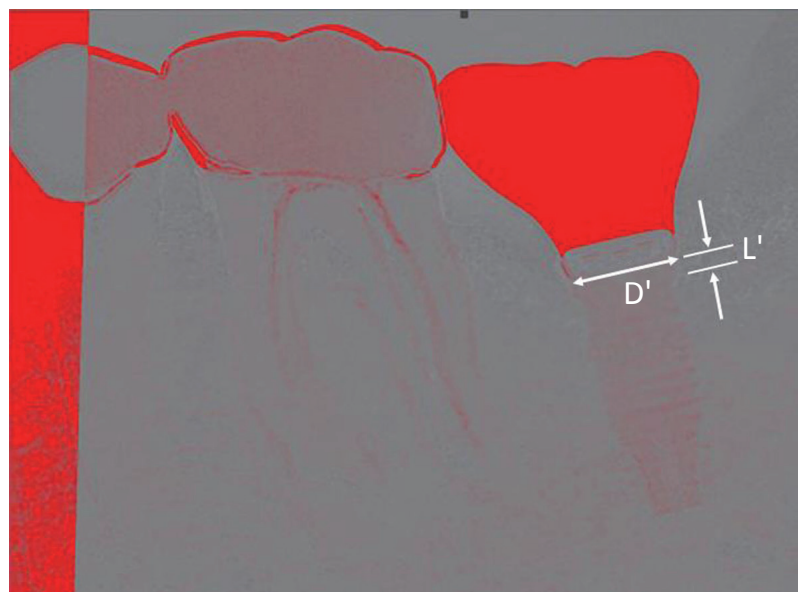

Fig. 2. References used to measure the actual marginal bone loss. D': diameter of implant fixture platform on digital subtraction image, L': marginal bone loss on digital subtraction image.

\section{결과}

\section{Platform matching 및 platform switching 임플란트의 변연골 소실량}

Platform matching 임플란트는 $1.16 \pm 0.54 \mathrm{~mm}$, platform switching 임플란트는 $0.68 \pm 0.27 \mathrm{~mm}$ 의 변연 골 소실을 나타내어 platform switching을 시행한 임플 란트의 변연골 소실이 유의하게 적었다(Table 2, Fig. 3).

\section{2. 임플란트 직경에 따른 platform matching 및 platform switching 임플란트의 변연골 소실량}

임플란트의 직경은 $3.75-6.0 \mathrm{~mm}$ 의 분포를 보이며, 각 제조사 별로 동일하지 않으므로 3.75 - $4.5 \mathrm{~mm}, 4.9$ $6.0 \mathrm{~mm}$ 의 2 개의 군으로 분류하여 측정하였다. 임플란 트 직경에 따른 변연골 소실은 차이가 없었으며, 같은 군에서 platform switching 임플란트의 변연골 소실이 적었다(Table 3, Fig. 4).

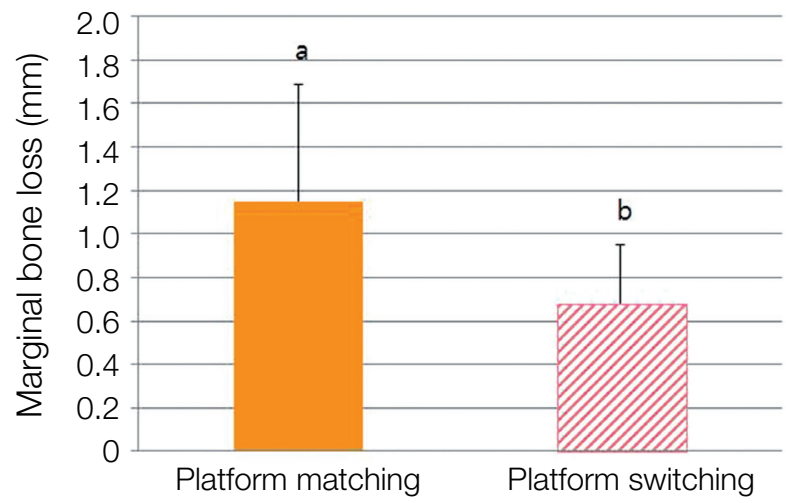

Platform type

Fig. 3. Marginal bone loss around platform matching and platform switching implants.

Table 2. Marginal bone loss around platform matching and platform switching implants

\begin{tabular}{ccccc}
\hline \multirow{2}{*}{$\begin{array}{c}\text { Platform type } \\
\text { Number of implant (n) }\end{array}$} & \multicolumn{3}{c}{$\begin{array}{c}\text { Marginal bone loss (mm) } \\
\text { (mean } \pm \text { SD) }\end{array}$} \\
\hline Platform matching & 80 & $1.17 \pm 0.57$ & $1.14 \pm 0.57$ & $1.16 \pm 0.54^{\mathrm{a}}$ \\
Platform switching & 70 & $0.68 \pm 0.29$ & $0.67 \pm 0.33$ & $0.68 \pm 0.27^{\mathrm{b}}$ \\
\hline
\end{tabular}

Different letters are significantly different (Tukey HSD test, $P<0.05$ ). 


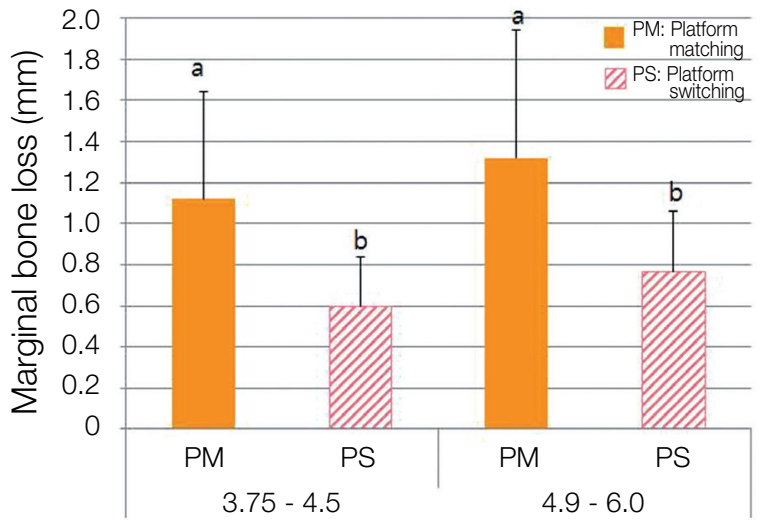

Implant diameter $(\mathrm{mm})$

Fig. 4. Marginal bone loss around implants according to implant diameter.

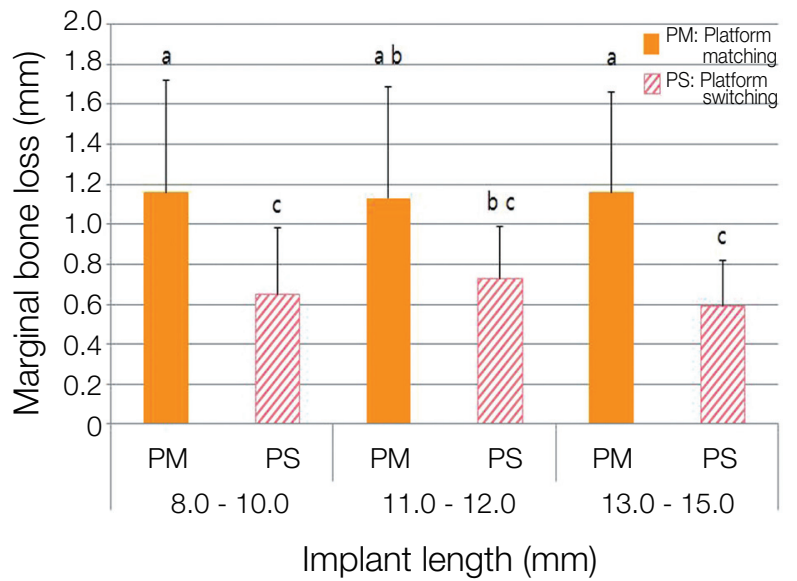

Fig. 5. Marginal bone loss around implants according to implant length.

Table 3. Marginal bone loss around implants according to implant diameter

\begin{tabular}{cccccc}
\hline $\begin{array}{c}\text { Implant diameter } \\
(\mathrm{mm})\end{array}$ & Platform type & $\begin{array}{c}\text { Number of } \\
\text { implants }(\mathrm{n})\end{array}$ & \multicolumn{3}{c}{$\begin{array}{c}\text { Marginal bone loss (mm) } \\
\text { (mean } \pm \text { SD) } \\
\text { Distal }\end{array}$} \\
\hline $3.75-4.5$ & PM & 65 & $1.12 \pm 0.54$ & $1.12 \pm 0.55$ & $1.12 \pm 0.52^{\mathrm{a}}$ \\
& PS & 40 & $0.65 \pm 0.27$ & $0.57 \pm 0.27$ & $0.60 \pm 0.24^{\mathrm{b}}$ \\
$4.9-6.0$ & PM & 15 & $1.39 \pm 0.65$ & $1.24 \pm 0.64$ & $1.32 \pm 0.62^{\mathrm{a}}$ \\
& PS & 30 & $0.73 \pm 0.32$ & $0.81 \pm 0.37$ & $0.77 \pm 0.29^{\mathrm{b}}$ \\
\hline
\end{tabular}

PM, platform matching; PS, platform switching.

Different letters are significantly different (Tukey HSD test, $P<0.05)$.

Table 4. Marginal bone loss around implants according to implant length

\begin{tabular}{cccccc}
\hline $\begin{array}{c}\text { Implant length } \\
(\mathrm{mm})\end{array}$ & Platform type & $\begin{array}{c}\text { Number of } \\
\text { implants }(\mathrm{n})\end{array}$ & \multicolumn{3}{c}{$\begin{array}{c}\text { Marginal bone loss (mm) } \\
\text { (mean } \pm \text { SD) }\end{array}$} \\
\hline $8.0-10.0$ & PM & 53 & $1.19 \pm 0.59$ & $1.13 \pm 0.59$ & $1.16 \pm 0.46^{\mathrm{a}}$ \\
& PS & 15 & $0.68 \pm 0.39$ & $0.62 \pm 0.30$ & $0.65 \pm 0.33^{\mathrm{c}}$ \\
$11.0-12.0$ & PM & 11 & $1.10 \pm 0.59$ & $1.16 \pm 0.59$ & $1.13 \pm 0.56^{\mathrm{ab}}$ \\
& PS & 37 & $0.69 \pm 0.27$ & $0.78 \pm 0.36$ & $0.73 \pm 0.26^{\mathrm{bc}}$ \\
$13.0-15.0$ & PM & 16 & $1.16 \pm 0.51$ & $1.16 \pm 0.53$ & $1.16 \pm 0.50^{\mathrm{a}}$ \\
& PS & 18 & $0.67 \pm 0.26$ & $0.50 \pm 0.22$ & $0.59 \pm 0.23^{\mathrm{c}}$ \\
\hline
\end{tabular}

PM, platform matching; PS, platform switching.

Different letters are significantly different (Tukey HSD test, $P<0.05$ ).

\section{3. 임플란트 길이에 따른 platform matching 및 platform switching 임플란트의 변연골 소실량}

임플란트의 길이는 $8.0-15.0 \mathrm{~mm}$ 의 분포를 보이며, 각 제조사 별로 동일하지 않으므로 $8.0-10.0 \mathrm{~mm}, 11.0$
- $12.0 \mathrm{~mm}, 13.0$ - $15.0 \mathrm{~mm}$ 의 범위로 분류하였다. 임플 란트 길이에 따른 변연골 소실량은 유의성 있는 차이가 없었으며, 임플란트 길이가 8.0 - $10.0 \mathrm{~mm}, 13.0$ - 15.0 $\mathrm{mm}$ 의 군에서는 platform switching 임플란트의 변연골 소실이 적었다(Table 4, Fig. 5). 


\section{4. 지대주 연결방법에 따른 platform matching 및 platform switching 임플란트의 변연골 소실량}

임플란트는 지대주 연결방법에 따라 외부육각 (external hex) 연결구조와 내부육각(internal hex) 연결 구조로 구분할 수 있다. 외부육각 연결구조 임플란트에 서는 platform matching, platform switching에 따른 변 연골 소실의 차이가 없었으며, 내부육각 연결구조 임플 란트에서는 platform switching 임플란트의 변연골 소실

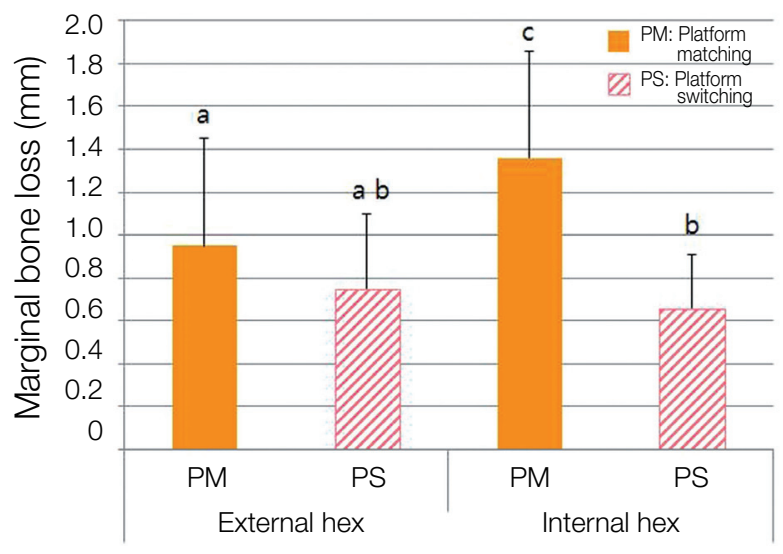

Implant-abutment connection type

Fig. 6. Marginal bone loss around implants according to implant-abutment connection type.
이 적었다(Table 5, Fig. 6).

\section{5. 보철물 연결고정 유무에 따른 platform matching 및 platform switching 임플란트의 변연골 소실량}

인접한 보철물과 연결고정한 임플란트 수복물은 104 개, 단일치아 보철물로 수복한 임플란트 수복물은 46 개였다. 보철물 연결고정 유무에 따른 변연골 소실량은

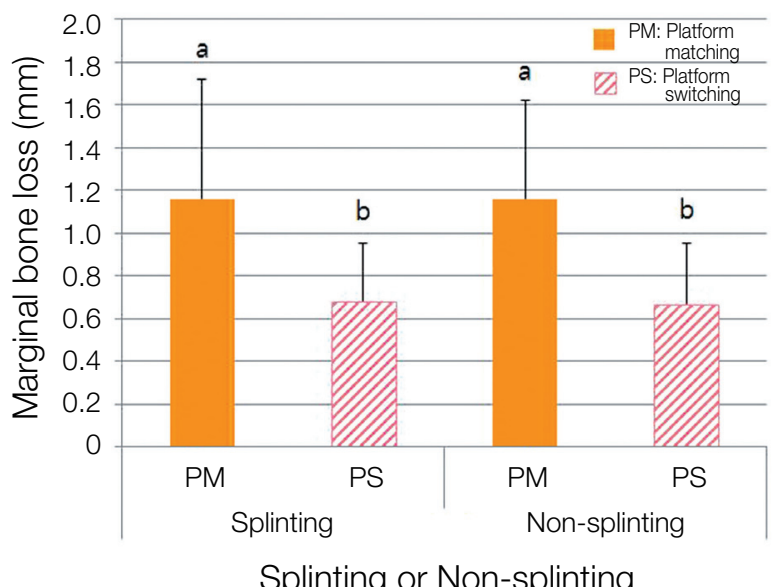

Fig. 7. Marginal bone loss around implants according to implant prosthesis splinting.

Table 5. Marginal bone loss around implants according to implant-abutment connection type

\begin{tabular}{cccccc}
\hline $\begin{array}{c}\text { Implant-abutment } \\
\text { connection type }\end{array}$ & Platform type & $\begin{array}{c}\text { Number of } \\
\text { implants (n) }\end{array}$ & \multicolumn{3}{c}{$\begin{array}{c}\text { Marginal bone loss (mm) } \\
\text { (mean } \pm \text { SD) } \\
\text { Distal }\end{array}$} \\
\hline External hex & PM & 40 & $0.97 \pm 0.52$ & $0.93 \pm 0.55$ & $0.95 \pm 0.50^{\mathrm{a}}$ \\
& PS & 15 & $0.73 \pm 0.38$ & $0.77 \pm 0.41$ & $0.75 \pm 0.35^{\mathrm{ab}}$ \\
Internal hex & PM & 40 & $1.37 \pm 0.54$ & $1.35 \pm 0.52$ & $1.36 \pm 0.50^{\mathrm{c}}$ \\
& PS & 55 & $0.67 \pm 0.27$ & $0.64 \pm 0.31$ & $0.66 \pm 0.25^{\mathrm{b}}$ \\
\hline
\end{tabular}

PM, platform matching; PS, platform switching.

Different letters are significantly different (Tukey HSD test, $P<0.05$ ).

Table 6. Marginal bone loss around implants according to implant prosthesis splinting

\begin{tabular}{cccccc}
\hline $\begin{array}{c}\text { Splinting or } \\
\text { Non-splinting }\end{array}$ & Platform type & $\begin{array}{c}\text { Number of } \\
\text { implants }(\mathrm{n})\end{array}$ & \multicolumn{3}{c}{$\begin{array}{c}\text { Marginal bone loss (mm) } \\
\text { (mean } \pm \text { SD) } \\
\text { Distal }\end{array}$} \\
\hline Splinting & PM & 61 & $1.14 \pm 0.57$ & $1.18 \pm 0.61$ & $1.16 \pm 0.56^{\mathrm{a}}$ \\
& PS & 43 & $0.72 \pm 0.30$ & $0.65 \pm 0.33$ & $0.68 \pm 0.27^{\mathrm{b}}$ \\
Non-splinting & PM & 19 & $1.28 \pm 0.55$ & $1.04 \pm 0.43$ & $1.16 \pm 0.46^{\mathrm{a}}$ \\
& PS & 27 & $0.63 \pm 0.28$ & $0.71 \pm 0.34$ & $0.67 \pm 0.28^{\mathrm{b}}$ \\
\hline
\end{tabular}

PM, platform matching; PS, platform switching.

Different letters are significantly different (Tukey HSD test, $P<0.05$ ). 
유의성 있는 차이가 없었으며, 같은 군에서는 platform switching을 한 임플란트의 변연골 소실량이 적었다 (Table 6, Fig. 7).

\section{고찰}

임플란트를 이용한 보철수복 후 임플란트의 변연골 소실은 피할 수 없는 것으로 보고되며, ${ }^{1-5}$ 많은 연구에서 임플란트 보철의 교합압은 임플란트의 치조정 부위에 집중되기 때문에 임플란트 고정체의 첫 번째 나사선 높 이까지 치조정골이 재형성되고, 연조직이 임플란트 주 변으로 생물학적 폭경이라고 불리는 점막 방어벽을 형 성한다고 하였다. ${ }^{6,9}$

Ericsson 등 ${ }^{10}$ 의 조직학적 연구에 따르면 임플란트 고 정체와 지대주의 접합부위를 중심으로 $1.5 \mathrm{~mm}$ 의 염증 세포가 침윤되는 지대주 염증세포 침윤대( 'abutment' inflammatory cell infiltrate, aICT)가 존재하며, 그 하방 으로 약 $1 \mathrm{~mm}$ 의 건전한 결합조직이 존재하기 때문에 변연골이 소실된다고 하였다. 또한 Hermann 등 ${ }^{5}$ 은 방 사선학적 연구를 통해 일반적인 2-piece의 임플란트에 서 미세간극이 존재하여 초기 치유기간 동안에 변연골 재형성이 빠르게 진행된다고 하였다. 이외에도 임플란 트 식립시 외상과 임플란트 주변 점막에 염증이 발생할 경우, 그리고 임플란트 경부 디자인이 거칠고 경사가 질 경우 교합력을 골에 전달하기 때문에 변연골 소실은 피 할 수 없다. ${ }^{4}$ 따라서 임플란트의 장기적인 성공을 위해 서는 임플란트의 변연골이 안정화되도록 유지관리해야 한다.

임플란트를 이용한 치료의 초창기에 $5.0 \mathrm{~mm}, 6.0 \mathrm{~mm}$ 의 넓은 직경의 고정체에 직경이 일치하는 지대주를 이 용하지 못하는 경우 $4.1 \mathrm{~mm}$ 의 지대주를 이용한 결과 변 연골이 보존되는 것을 관찰한 것을 시작으로 platform switching의 개념이 시작되었다. ${ }^{4}$

Cappiello 등 ${ }^{11}$ 은 전체 131 개의 임플란트 보철 수복물 을 대상으로 1년 동안 임상적 및 방사선학적 연구를 통 해 platform matching 임플란트의 경우 $1.67 \pm 0.37 \mathrm{~mm}$ 의 변연골이 소실되었고, platform switching 임플란트 는 $0.95 \pm 0.32 \mathrm{~mm}$ 의 변연골이 소실되었다고 하였다. 이에 platform switching이 임플란트 주변 치조정골의 흡수를 줄이며 임플란트의 장기적인 성공률을 높인다고 하였다.

De Almeida 등 ${ }^{12}$ 은 6 - 60개월 정기검진을 시행한 환 자를 대상으로 변연골 소실량을 비교한 결과, platform matching 임플란트의 변연골 소실은 $2.30 \mathrm{~mm}$ 인 반면에 platform switching 임플란트의 변연골 소실은 $0.27 \mathrm{~mm}$ 를 보였다. 결국 임플란트 고정체와 지대주의 접합부위 를 수평적으로 재위치시키는 platform switching이 임플 란트의 변연골 소실을 최소화하는데 효과적이라고 하였 다.

본 연구에서도 platform matching 임플란트는 $1.16 \pm$ $0.54 \mathrm{~mm}$, platform switching 임플란트는 $0.68 \pm 0.27$ $\mathrm{mm}$ 의 변연골 소실을 나타내어, platform matching 임 플란트에 비하여 platform switching을 시행한 임플란 트의 변연골 소실이 유의하게 적었다. 이는 platform switching을 통해 변연골 재형성 부위가 임플란트 platform 내측으로 이동하고 생물학적 폭경이 수평적으 로 늘어나서, platform switching 임플란트 주변 변연골 이 platform matching 임플란트에 비해 좀 더 보존되었 기 때문으로 사료된다.

하지만 Enkling 등 ${ }^{13}$ 의 연구에서는 임플란트 식립 시 와 보철수복을 한 1 년 후 임플란트의 변연골 소실량 을 측정한 결과 platform matching 임플란트의 변연 골 소실은 $0.58 \pm 0.55 \mathrm{~mm}$, platform switching 임플 란트의 변연골 소실은 $0.53 \pm 0.35 \mathrm{~mm}$ 였다. 결과적으 로 platform matching, platform switching 임플란트에 서 변연골 소실량의 유의한 차이를 보이지 않았다. 이는 platform matching 임플란트와 platform switching 임플 란트의 지대주 직경이 동일한 조건에서 변연골 소실량 을 비교했기 때문에 변연골 소실의 차이가 발생하지 않 았다고 하였다.

Himmlová 등 ${ }^{14}$ 은 임플란트를 대상으로 3차원 유한요 소분석을 시행한 결과, 임플란트의 응력이 대부분 임플 란트의 경부에 집중되고, 임플란트의 직경과 길이가 증 가함에 따라 응력이 줄어든다고 보고하였다. 하지만 임 플란트 길이 증가에 따라 응력이 줄어드는 효과보다 임 플란트의 직경이 증가함에 따른 응력분산 효과가 더 크 다고 하였다. 또한 Lee 등 ${ }^{15}$ 은 단일치 임플란트에서 임플 란트 고정체와 지대주 직경을 달리하여 광탄성 응력을 분석한 결과, 임플란트 고정체의 직경이 증가할수록 고 정체 변연부의 응력집중이 낮게 나타났다고 하였다.

하지만 Montaser ${ }^{16}$ 는 120 명의 150 개 단일 임플란트 보철물을 대상으로 $3.5 \mathrm{~mm}, 4.3 \mathrm{~mm}, 5.0 \mathrm{~mm}$ 직경의 임 플란트의 변연골 소실량을 식립 1년, 2년, 3년 후 방사선 사진을 이용하여 측정한 결과, 임플란트의 직경이 클수 록 임플란트의 변연골이 더 소실된다고 보고하였다. 
치조정골의 소실을 줄이거나 최소화할 수 있으나 임플 란트의 지대주 연결방법에 따른 영향에 대한 연구가 아 직은 미비한 실정이기 때문에 좀 더 많은 연구가 뒷받침 되어야 한다고 하였다. 그리고 임상가들은 임플란트 주 변 치조정골의 재형성에 영향을 미칠 수 있는 미세 움직 임 또는 미세 누출이 존재하지 않는 임플란트 시스템을 신중하게 선택해야 한다고 하였다.

일반적으로 보철물을 연결고정할 경우 임플란트 사 이에서 교합압을 분산시키며 골과 임플란트 계면에 가 해지는 수평적인 힘을 최소화하고 골과 임플란트 표면 의 접촉면을 증가시켜 임플란트의 장기간 성공을 높인 다고 한다. 하지만 Yilmaz 등 ${ }^{27}$ 은 환자의 CT 자료를 기 초로 제작한 하악 모형에 2개의 시멘트 유지형 보철물 을 연결고정한 것과 그렇지 않은 것에 일정한 힘을 가한 후 3차원 이미지 상관법을 이용하여 응력분포를 확인 한 결과, 2 개의 보철물을 연결고정한 것과 분리한 것의 유의한 차이를 보이지 않았다. 본 연구에서도 인접 임 플란트 보철물과 연결고정한 것과 단일 임플란트 보철 물의 변연골 소실량은 유의차를 보이지 않았으며, 단지 platform switching에 의해 변연골 소실이 줄어들었음을 확인하였다.

임플란트의 안정성을 평가하기 위한 방법으로는 임상 검사, periotest, resonance frequency analysis (RFA), 방 사선학적 측정, 조직학적 표본관찰 등의 방법이 있다. 이와 같은 여러 가지 방법 중에서 비파괴적이며 경제적 인 방법으로 치근단 방사선 사진을 촬영하여 임플란트 의 변연골 소실 여부를 확인하게 된다. ${ }^{28}$ 하지만 치근단 방사선 사진을 임플란트 장축에 수직으로 촬영하지 않 았거나 임플란트 식립 시와 최근 내원 시의 방사선 사진 의 촬영 각도가 일치하지 않은 경우에는 변연골 소실량 을 정확하게 측정하기 어렵다. 또한 Bittar-Cortez 등 ${ }^{29}$ 은 변연골 높이를 치근단 방사선 사진과 디지털 공제 영 상으로 측정하여 비교한 연구에서 관찰자 간 측정한 변 연골 높이에 유의한 차이를 보이기 때문에, 변연골 측 정 시 관찰자는 매우 주의하여야 한다고 하였다. 또한 Hürzeler 등 ${ }^{30}$ 은 보철 수복 시와 기능 1 년 후 platform switching 임플란트의 변연골 흡수량을 측정하기 위해 자가중합형 레진을 이용하여 환자 개개인마다 방사선 사진 형판을 만들어 표준화된 방사선 사진을 촬영하였 는데, 이러한 방법 등을 통해서 좀 더 정확한 임플란트 의 변연골 높이를 측정할 수 있을 것으로 사료된다.

Dunn 등 $^{31}$ 은 디지털 공제 영상을 획득 시 확대된 영상
본 연구에서는 임플란트 직경에 따른 변연골 소실에 차이가 없었다. 그러나 통계적으로 유의하지는 않았지 만 임플란트의 직경이 큰 군에서 변연골 소실량이 많았 고, 그 이유는 임플란트 식립 수술 시 응력이 더 크게 발 생하였으며 골질이 나쁜 부위에 직경이 큰 임플란트를 선택하는 경우가 많아 변연골이 좀 더 흡수된 것으로 추 측된다.

Pierrisnard 등 ${ }^{17}$ 은 임플란트 길이에 따른 3 차원 유한 요소분석 결과 임플란트의 길이에 관계없이 임플란트 주변의 최대응력은 비슷하다고 하였으며, 본 연구에서 도 임플란트 길이에 따른 변연골 소실의 차이가 없었다. 또한 Myung 등 $^{18}$ 도 디지털 공제술을 이용하여 임플란트 의 변연골 소실량을 측정한 연구에서 임플란트 길이에 따른 변연골 소실의 차이가 없었다고 보고하였다. 이는 임플란트 길이와 상관없이 응력은 임플란트 경부에 집 중되기 때문일 것으로 추측되며, 본 연구에서도 임플란 트 길이에 따른 임플란트 주변 변연골 흡수량은 유의한 차이가 없었다.

Gurgel-Juarez 등 $^{19}$ 은 임플란트 지대주 연결형태 및 platform 형태에 따라 상악 전치부 모형으로 3차원 유한 요소분석을 시행하였다. 그 결과 내부육각 연결구조의 임플란트에 비해 외부육각 연결구조의 임플란트에서 응 력집중이 덜 발생한다고 하였으며, platform switching 의 효과로 인하여 응력이 적게 집중된다고 하였다. Yang 과 Maeda ${ }^{20}$ 도 platform switching 임플란트에서 응력이 덜 발생하며, platform switching의 효과가 외부육각 연 결구조의 임플란트에서 더 효과적이라고 하였다.

몇몇 연구에서는 내부육각 연결구조의 임플란트가 고 정체 내면에서 좀 더 넓고 깊은 접촉면을 가지기 때문에 안정성이 높아 외부육각 연결구조의 임플란트보다 응력 분산에 더 효과적이라고 하였다. ${ }^{21,22}$ 또한 $\mathrm{KoO}$ 등 ${ }^{23}$ 은 방 사선 사진을 통하여 외부육각 연결구조 임플란트 주변 의 치조정골 소실이 내부육각 연결구조 임플란트에 비 하여 더 많았다고 하였다. $\mathrm{Kim}$ 등 $^{24}$ 은 3 차원 유한요소분 석을 통하여 각기 다른 내부연결 방식의 임플란트에서 응력분포 양상이 다양하게 나타났다고 하였다.

본 연구에서는 외부육각 연결구조의 임플란트에서는 platform matching, platform switching에 따른 변연골 소실에 따른 차이가 없었으며, 내부육각 연결구조의 경 우 platform switching 임플란트에서 변연골 소실이 유 의하게 적었다.

최근 Schwarz 등 ${ }^{25,26}$ 은 platform switching으로 인하여 
에서 참고점을 설정하여 두 장의 방사선 사진을 공제할 경우 정확한 공제 영상을 사용할 수 있다고 하였다. 이 에 본 연구에서는 최근 디지털 시스템으로 방사선 사진 을 판독할 수 있고 8개의 참고점을 선택하여 디지털 공 제 영상을 획득할 있는 Emago advanced v5.6 프로그램 을 사용하여 임플란트의 변연골 소실량을 측정하였다. 하지만 반복 가능하며 재현성이 높은 치근단 방사선 사 진을 촬영하기 위해서는 필름유지기구를 사용하거나 기 타 다른 방사선 촬영 장치가 개발되어야 할 것으로 사료 된다.

본 연구에서 임플란트의 platform 형태에 따라 임플 란트 직경, 길이, 지대주 연결방법 및 보철물 연결고정 유무가 임플란트의 변연골 소실량에 미치는 영향을 디 지털 공제술을 이용하여 측정하고 비교한 결과를 도출 하였다. 연구 목표에 맞추어 환자의 진료기록부를 토대 로 환자를 선택하고 방사선 사진을 기준으로 변연골 소 실량을 측정하여 비교하였는데, 추후 전향적인 연구 목 표를 가지고 정기적인 검진을 통해 일정기간 동안 임플 란트의 변연골 소실량을 측정해야하며 장기적인 결과가 축적되어야 할 것으로 사료된다.

또한 환자의 전반적인 치주 상태가 임플란트의 변연 골 소실에 영향을 주었는지를 확인하기 위해서 해당 임 플란트 뿐만 아니라 인접 치아의 치조골 높이의 변화 유 무도 함께 측정하여 비교하는 연구가 필요할 것이다. 추 가적으로 변연골 소실량을 측정하는 임플란트가 최후방 구치일 경우와 근원심으로 인접치가 존재하는 경우 등 인접치의 영향이 임플란트의 변연골 소실에 미치는 영 향에 대한 연구가 필요할 것으로 생각된다.

\section{결론}

2005년 6월부터 2013년 5월 사이에 원광대학교 치과 병원 임플란트 센터에서 임플란트를 식립하고 보철치 료를 받은 환자 82 명(남자 43명, 여자 39명)의 임플란 트 150개(platform matching 임플란트 80개, platform switching 임플란트 70개)를 6 - 63개월(평균 24.9개월) 동안 관찰한 후향적 임상 연구를 통하여 다음과 같은 결 론을 얻었다.

1. Platform matching 임플란트는 $1.16 \pm 0.54 \mathrm{~mm}$, platform switching 임플란트는 $0.68 \pm 0.27 \mathrm{~mm}$ 의 변연골 소실을 나타내어 platform switching을 시행 한 임플란트의 변연골 소실이 적었다.
2. 임플란트의 직경과 길이의 차이, 보철물 연결고 정 유무와 관계없이 변연골 소실량은 platform switching 임플란트에서 적었다.

3. 내부육각 연결구조 임플란트에서는 platform switching 임플란트의 변연골 소실이 적었으며, 외부육각 연결구조 임플란트에서는 platform matching, platform switching 임플란트의 변연골 소실의 차이가 없었다.

\section{Acknowledgements}

본 연구는 2013년 원광대학교 교비 지원에 의해 연구 되었음.

\section{References}

1. Adell R, Lekholm U, Rockler B, Brånemark PI. A 15-year study of osseointegrated implants in the treatment of the edentulous jaw. Int J Oral Surg 1981;10:387-416.

2. Smith DE, Zarb GA. Criteria for success of osseointegrated endosseous implants. J Prosthet Dent 1989;62:567-72.

3. Albrektsson T, Zarb G, Worthington P, Eriksson AR. The long-term efficacy of currently used dental implants: a review and proposed criteria for success. Int J Oral Maxillofac Implants 1986;1:11-25.

4. Oh TJ, Yoon J, Misch CE, Wang HL. The causes of early implant bone loss: myth of science? J Periodontol 2002;73:322-33.

5. Hermann JS, Cochran DL, Nummikoski PV, Buser D. Crestal bone changes around titatium implants. A radiographic evaluation of unloaded nonsubmerged and submerged implants in the canine mandible. J Periodontol 1997;68:1117-30.

6. Lazzara RJ, Porter SS. Platform switching: a new concept in implant dentistry for controlling postrestorative crestal bone levels. Int J Periodontics Restorative Dent 2006;26:9-17.

7. Brägger U, Bürgin W, Lang NP, Buser D. Digital subtraction radiography for the assessment of changes in peri-implant bone density. Int J Oral Maxillofac Implants 1991;6:160-6.

8. Han WJ. A comparison of subtracted images from 
dental subtraction programs. Korean J Oral Maxillofac Radiol 2002;32:147-51.

9. Pilliar RM, Deporter DA, Watson PA, Valiquette N. Dental implant design-effect on bone remodeling. J Biomed Mater Res 1991;25:467-83.

10. Ericsson I, Persson LG, Berglundh T, Marinello CP, Lindhe J, Klinge B. Different types of inflammatory reactions in peri-implant soft tissues. J Clin Periodontol 1995;22:255-61.

11. Cappiello M, Luongo R, Di Iorio D, Bugea C, Cocchetto R, Celletti R. Evaluation of peri-implant bone loss around platform-switched implants. Int J Periodontics Restorative Dent 2008;28:347-55.

12. de Almeida FD, Carvalho AC, Fontes M, Pedrosa A, Costa R, Noleto JW, Mourão CF. Radiographic evaluation of marginal bone level around internalhex implants with switched platform: a clinical case report series. Int J Oral Maxillofac Implants 2011; 26:587-92.

13. Enkling N, Jöhren P, Klimberg V, Bayer S, Mericske-Stern R, Jepsen S. Effect of platform switching on peri-implant bone levels: a randomized clinical trial. Clin Oral Implants Res 2011;22:1185-92.

14. Himmlová L, Dostálová T, Kácovský A, Konvicková S. Influence of implant length and diameter on stress distribution: a finite element analysis. J Prosthet Dent 2004;91:20-5.

15. Lee JH, Cho HW. Photoelastic stress analysis of single implant restoration according to implant fixture size and abutment diameter. J Dent Rehabil Appl Sci 2008;24:253-67.

16. Al-Qutub MN. Radiologic evaluation of the marginal bone loss around dental implants with different neck diameters. Pakistan Oral \& Dental Journal 2011;31:150-3.

17. Pierrisnard L, Renouard F, Renault P, Barquins M. Influence of implant length and bicortical anchorage on implant stress distribution. Clin Implant Dent Relat Res 2003;5:254-62.

18. Myung TS, Jung SH, Kim TY, Kim YL. Clinical study on the survival rate and marginal bone resorption of short implants. J Dent Rehabil Appl Sci 2012;28:1-13.

19. Gurgel-Juarez NC, de Almeida EO, Rocha EP, Freitas AC Jr, Anchieta RB, de Vargas LC, Kina S,
França FM. Regular and platform switching: bone stress analysis varying implant type. J Prosthodont 2012;21:160-6.

20. Yang TC, Maeda Y. The biomechanical effect of platform switching on external- and internal-connection implants. Int J Oral Maxillofac Implants 2013;28:143-7.

21. Maeda Y, Satoh T, Sogo M. In vitro differences of stress concentrations for internal and external hex implant-abutment connections: a short communication. J Oral Rehabil 2006;33:75-8.

22. Chun HJ, Shin HS, Han CH, Lee SH. Influence of implant abutment type on stress distribution in bone under various loading conditions using finite element analysis. Int J Oral Maxillofac Implants 2006;21:195-202.

23. Koo KT, Lee EJ, Kim JY, Seol YJ, Han JS, Kim TI, Lee YM, Ku Y, Wikesjö UM, Rhyu IC. The effect of internal versus external abutment connection modes on crestal bone changes around dental implants: a radiographic analysis. J Periodontol 2012;83:1104-9.

24. Kim YL, Cho HW, JB. Three dimensional finite element analysis of internally connected implant systems. J Korean Acad Prosthodont 2006;44:85102.

25. Schwarz F, Hegewald A, Becker J. Impact of implant-abutment connection and positioning of the machined collar/microgap on crestal bone level changes: a systematic review. Clin Oral Implants Res 2014;25:417-25.

26. Schwarz F, Alcoforado G, Nelson K, Schaer A, Taylor T, Beuer F, Strietzel FP. Impact of implantabutment connection, positioning of the machined collar/microgap, and platform switching on crestal bone level changes. Camlog foundation consensus report. Clin Oral Implants Res 2014;25:1301-3.

27. Yilmaz B, Mess J, Seidt J, Clelland NL. Strain comparisons for splinted and nonsplinted cement-retained implant crowns. Int J Prosthodont 2013;26: 235-8

28. So SS, Noh HS, Kim CS, Choi SH, Chae JK, Kim CK, Cho KS. Evaluation of peri-implant bone density changes in Brånemark implants by computer assisted densitometric image analysis (CADIA). J 
Korean Acad Periodontol 2007;37:137-50.

29. Bittar-Cortez JA, Passeri LA, de Almeida SM, Haiter-Neto F. Comparison of peri-implant bone level assessment in digitized conventional radiographs and digital subtraction images. Dentomaxillofac Radiol 2006;35:258-62.

30. Hürzeler M, Fickl S, Zuhr O, Wachtel HC. Periimplant bone level around implants with platform- switched abutments: preliminary data from a prospective study. J Oral Maxillofac Surg 2007;65(7 Suppl 1):33-9.

31. Dunn SM, van der Stelt PF, Ponce A, Fenesy K, Shah S. A comparison of two registration techniques for digital subtraction radiography. Dentomaxillofac Radiol 1993;22:77-80. 


\section{디지털 공제술을 이용한 platform switching 임플란트의 변연골 소실에 대한 연구}

\section{김치윤, 김성숙, 인희선, 김유리*}

원광대학교 치과대학 치과보철학교실

목적: 본 연구는 platform matching, platform switching을 시행한 임플란트의 변연골 소실을 비교하여 platform switching 개념의 임상적 의의를 평가하고자 한다.

연구 재료 및 방법: 원광대학교 치과병원 임플란트 센터에서 치료를 진행한 환자를 대상으로 임플란트 식립 시기, 직 경, 길이, 지대주 연결방법 및 보철물 연결고정 유무를 조사하였다. 변연골 소실량을 측정하기 위해서 Emago advanced v5.6 프로그램을 사용하여 임플란트 식립 시와 가장 최근 내원 시의 치근단 방사선 사진을 비교하였다.

결과: 환자 82명의 임플란트 150개를 대상으로 6 - 63개월 동안 관찰한 결과 platform matching 임플란트는 $1.16 \pm 0.54$ $\mathrm{mm}$, platform switching 임플란트는 $0.68 \pm 0.27 \mathrm{~mm}$ 의 변연골 소실을 나타내었다.

결론: Platform switching을 시행함으로써 임플란트의 변연골 소실을 줄이는 효과가 있는 것으로 사료된다.

(구강회복응용과학지 2015;31(1):33-44)

주요어: platform switching; marginal bone loss; digital subtraction image

*교신저자: 김유리

(570-749) 전북 익산시 익산대로 460 원광대학교 치과대학 치과보철학교실

Tel: 063-859-2938 | Fax: 063-857-4824 | E-mail: pro11@wku.ac.kr

접수일: 2014년 12월 16일 | 수정일: 2015년 3월 8일 | 채택일: 2015년 3월 2일 